\title{
KEMAMPUAN DUA SPESIES Enterobacter sp. SEBAGAI BAKTERI PEMACU PERTUMBUHAN TANAMAN KENTANG (Solanum tuberosum L.) PADA KONDISI CEKAMAN KEKERINGAN
}

\author{
Khoirun Enisa Maharina, Nurul Aini dan Luqman Qurata Aini \\ Program Studi Ilmu Tanaman, Program Pasca Sarjana Fakultas Pertanian, \\ Universitas Brawijaya
}

\begin{abstract}
Enterobacter xiangfangensis and Enterobacter cloaceae are known to have the ability as a phosfat solubilizing and producing hormone IAA. Their also have ability to survive under drought stress in vitro assay conditions. Both of these bacteria has good potential as a potato plant growth promoting bacteria, especially in drought stress conditions. This is an alternative to improve tolerance and growth of the potato crop in drought stress conditions. The results showed that the level of drought stress $75 \%$ of field capacity can boost the potential of endophytic bacteria E. xiangfangensis in increasing leaf area, plant dry weight, root length and physiological activity i.e total phosphorus content in potato plants. Endophytic bacteria E. xiangfangensis is better to increase potato plant height than endophytic bacteria E. cloaceae. These results are supported by the results of potential test of E. xiangfangensis which have the advantage of producing hormones IAA compared with E. cloaceae. Furthermore, in drought stress conditions $50 \%$ of field capacity and $75 \%$ of field capacity have different effects on the observations of root length growth parameters potato plants.
\end{abstract}

Keywords : Endophytic, Enterobacter sp., Tolerance, Drought, Growth

\section{Pendahuluan}

Produktivitas kentang pada tahun 2012 tercatat 16,58 ton $\mathrm{ha}^{-1}$, sedangkan pada tahun 2013 mengalami penurunan sebesar 3,37\% menjadi 16,02 ton $\mathrm{ha}^{-1}$, selanjutnya pada tahun 2014 hanya mencapai 15,99 ton $\mathrm{ha}^{-1}$ (Kementerian Pertanian, 2015). Produktivitas tanaman kentang mengalami penurunan satu diantaranya disebabkan oleh perubahan iklim. Perubahan iklim yang terjadi di wilayah Indonesia pada beberapa tahun terakhir diketahui disebabkan oleh peristiwa el nino yaitu perpindahan masa air laut dari bagian barat Samudra Pasifik menuju ke arah timur Samudra Pasifik (Anonymous, 2015). Hal ini menyebabkan penurunan curah hujan, peningkatan suhu udara hingga menyebabkan kekeringan. Kondisi tersebut menyebabkan tanaman tumbuh pada kondisi tercekam karena kentang termasuk tanaman yang rentan terhadap peningkatan suhu dan kekeringan (Monneveux, Ramirez dan Pino, 2013). Kekeringan yang dialami oleh tanaman kentang pada fase vegetatif menyebabkan siklus hidup tanaman berlangsung lebih cepat, mengurangi jumlah daun, tinggi tanaman serta indeks luas daun (Deblonde dan Ledent, 2001). Aktivitas fisiologis yang terganggu saat terjadi kekeringan diantaranya ialah jumlah stomata, aktifitas membuka dan menutupnya stomata, laju fotosintesis, 
penyerapan unsur hara, serta kadar klorofil pada daun (Basu, Sharma dan Sukumaran, 1998). Kekeringan menyebabkan penurunan kualitas umbi yang dilihat dari bentuk, ukuran, bobot umbi serta kandungan karbohidrat (Hiller dan Thornton, 2008). Guna mengantisipasi hal tersebut, maka perlu dilakukan suatu upaya untuk meningkatkan toleransi tanaman terhadap cekaman kekeringan yaitu dengan cara mengaktifkan peran mikroorganisme indegnous yang dapat bersimbiosis dengan tanaman kentang.

Laboratorium Bakteriologi Jurusan

Hama Penyakit Tumbuhan Fakultas Pertanian UB memiliki sejumlah isolat bakteri endofit hasil isolasi dari tanaman kentang. Sejumlah bakteri endofit telah diuji kemampuannya sebagai agens pengendali hayati bakteri patogen Erwinia carotovora (Kartini, 2014) dan Ralstonia solanacearum (Yustianita, 2015). Pada penelitian sebelumnya telah diperoleh dua isolat bakteri endofit potensial yang diketahui berasal dari gensu Enterobacter yaitu Enterobacter xianfangensis dan Enterobacter cloaceae. Guna menguji efisiensi kedua bakteri tersebut maka dilakukan sebuah penelitian yang bertujuan untuk mengetahui potensi kedua isolat bekteri dalam meningkatkan pertumbuhan dan aktivitas fisiologis tanaman kentang varietas Nadia pada kondisi cekaman kekeringan.

\section{Metode Penelitian}

Penelitian dilaksanakan di lahan percobaan dengan menggunakan polibag. Lahan percobaan berada di Dusun Dadaprejo, Desa Pandanrejo, Kecamatan Bumiaji, Kota Batu. Ketinggian tempat lahan percobaan yaitu $800 \mathrm{~m}$ di atas permukaan laut (dpl). Penelitian dilaksanakan pada bulan Februari 2015 Mei 2016. Peralatan yang digunakan antara lain : timbangan digital, polibag ukuran $40 \times 40 \mathrm{~cm}$, penggaris, alat tulis, Leaf Area Meter (LAM), oven, kantong kresek dan papan label. Bahan yang digunakan antara lain : umbi bibit kentang varietas Nadia generasi ke-4, tanah, pupuk organik kotoran kambing yang telah difermentasi, pupuk NPK 16:16:16, bambu dan plastik penutup.

Rancangan percobaan disusun menggunakan Rancangan Acak Kelompok (RAK) Faktorial yang terdiri dari dua faktor. Faktor pertama yaitu jenis bakteri endofit, diantaranya E0 : tanpa bakteri endofit, E1: bakteri endofit isolat E117 dan E2 : bakteri endofit isolat E127. Faktor kedua yaitu tingkat cekaman kekeringan diantaranya K1 : 100\% kapasitas lapang (KL), K2 : 75\% $\mathrm{KL}, \mathrm{K} 3: 50 \% \mathrm{KL}$, dan $\mathrm{K} 4: 25 \% \mathrm{KL}$ sehingga terdapat 12 kombinasi perlakuan dan masing-masing diulang sebanyak 3 kali. Metode statistik yang digunakan untuk menguji hipotesis penelitian ini ialah analisis ragam (uji $\mathrm{F}$ ). Hasil analisis ragam yang berbeda nyata akan diuji lanjut menggunakan Uji Beda Nyata Terkecil antar perlakuan (BNT) taraf 5\%.

\section{Persiapan Media Tanam dan Pengukuran Kadar Air Kapasitas Lapang}

Media tanam yang digunakan yaitu campuran tanah dan pupuk organik dengan perbandingan 2:1. Media tanam disterilisasi menggunakan larutan formalin 4\% untuk menghilangkan kontaminasi dari mikroorganisme lain yang terdapat pada media. Sterilisasi dilakukan dengan cara menyemprotkan formalin 4\% secara merata, kemudian menutup media dengan plastik selama 5 hari dan membuka penutup plastik selama 5 hari. Penguapan bertujuan untuk menghilangkan uap air yang mengandung formalin 4\%. Setelah kering, media dimasukkan ke dalam 
polibag dengan bobot masing-masing polibag yaitu $8 \mathrm{~kg}$ media.

Pengukuran kadar air kapasitas lapang bertujuan untuk menetukan volume air yang diberikan sesuai dengan perlakuan cekaman kekeringan. Pengukuran kadar air kapasitas lapang dilakukan dengan cara mengambil 500 gram contoh media kemudian dimasukkan ke dalam polybag dan disiram dengan air hingga kondisi jenuh. Media tanam didiamkan selama 3 hari, sampai tidak ada air yang menetes. Bobot basah media tanam kemudian ditimbang sebagai nilai tanah basah ( $\mathrm{Tb}$ ). Kemudian media tanam dikering anginkan hingga diperoleh bobot konstan. Bobot kering media tanam ditimbang sebagai bobot tanah kering (Tk). Penentuan kadar air kapasitas lapang dihitung dengan rumus : (Hendriyani dan Setiari, 2009).

$$
\mathrm{KL}=\frac{(T b-T k)}{T k} \times 100 \%
$$

$\mathrm{KL}$ : Kadar air kapasitas lapang, Tb :

Bobot basah tanah $(\mathrm{g})$, Tk :

Bobot kering tanah (g)

\section{Persiapan Suspensi Bakteri Endofit}

Isolat bakteri endofit terpilih dibiakkan pada media NA selama 48 jam. Sebanyak dua loop jarum ose koloni bakteri endofit disuspensikan ke dalam $4 \mathrm{ml}$ aquades steril. Suspensi bakteri diukur hingga mencapai nilai $\mathrm{OD}_{600}=1$. Perhitungan jumlah koloni per $\mathrm{ml}$ dilakukan dengan metode pengenceran bertingkat hingga $10^{-9}$, dengan faktor pengenceran $10^{-1}$. Suspensi bakteri endofit yang diaplikasikan pada tanaman setara dengan kerapatan bakteri $10^{11}$. Volume suspensi yang disiramkan di sekitar perakaran yaitu $20 \mathrm{ml}$ per tanaman.

\section{Persiapan Umbi Bibit Kentang}

Umbi bibit yang digunakan yaitu umbi kentang varietas Nadia. Umbi yang digunakan ialah umbi utuh dengan bobot rata-rata $30 \mathrm{~g}$ dan bebas dari OPT. Sebelum ditanam, permukaan umbi dibersihkan dan dilakukan sterilisasi menggunakan larutan $\mathrm{NaOCl} 0,05 \%$. Umbi bibit direndam selama 5 menit, kemudian dibilas dengan air mengalir hingga bersih, kemudian dikering anginkan agar umbi tidak busuk saat ditanam. Setelah kering umbi bibit disimpan untuk ditanam pada esok hari.

\section{Penanaman}

Media tanam yang akan ditanami dibasahi terlebih dahulu untuk memudahkan pembuatan lubang tanam. Lubang tanam dibuat dengan kedalaman $10 \mathrm{~cm}$ menggunakan tugal. Umbi bibit ditanam dengan posisi tunas menghadap ke atas dan sepertiga umbi terlihat muncul dipermukaan media. Penanaman dilakukan pada waktu pagi hari sebelum matahari terik. Umbi ditanam secara tunggal yaitu terdapat satu umbi dalam satu polibag, sehingga terdapat 360 tanaman dalam satu percobaan.

\section{Inokulasi Bakteri Endofit}

Inokulasi bakteri endofit pada tanaman kentang dilakukan sebanyak tiga kali yaitu pada umur 0, 7 dan 14 hst. Inokulasi bakteri endofit dilakukan dengan cara menyiramkan suspensi bakteri endofit sebanyak $20 \mathrm{ml}$ ke dalam polibag atau daerah sekitar perakaran. Hal ini bertujuan agar bakteri dapat berkolonisasi dengan akar tanaman dengan lebih cepat. Waktu penyiraman dilakukan pada sore hari untuk menghindari evaporasi dan suhu tinggi pada siang hari yang dapat menyebabkan kematian pada bakteri endofit.

\section{Perlakuan Cekaman Kekeringan}

Perlakuan cekaman kekeringan diberikan dengan cara menyiramkan air sebanyak volume yang telah ditentukan. Perlakuan cekaman diberikan selama dua minggu berturut-turut yaitu pada akhir fase vegetatif hingga awal fase generatif yaitu umur 42 - 56 hst. Guna 
mempertahankan persentase kadar air tanah sesuai dengan perlakuan, maka pada saat aplikasi cekaman kekeringan dilakukan penutupan dengan plastik agar media tetap dalam kondisi yang ditentukan. Setelah tanaman berumur 56 hst, penyiraman dilakukan dengan volume dan waktu yang sama untuk semua perlakuan.

\section{Pengamatan Tanaman Kentang}

Pengamatan dilakukan secara non destruktif untuk parameter pertumbuhan dan persentase kerusakan tanaman. Pengamatan secara destruktif dilakukan terhadap parameter pertumbuhan dan fisiologis. Pengamatan hasil panen dilakukan pada saat tanaman sudah mengering dan siap untuk dipanen. Parameter yang diamati antara lain :

\section{a. Luas Daun}

Pengamatan luas daun dilakukan pada umur 56 dan 70 hst. Pengamatan dilakukan secara destruktif yaitu dengan cara mengambil semua bagian daun tanaman kentang yang telah membuka sempurna, kamudian diukur menggunakan alat Leaf Area Meter (LAM) untuk mengetahui total luas daun per tanaman dalam satuan $\mathrm{cm}^{2}$.

b. Bobot Kering Tanaman

Bobot kering tanaman diamati pada umur 56 dan 70 hst dengan cara memisahkan bagian daun, batang, dan akar kemudian dikeringkan pada suhu sekitar $80{ }^{\circ} \mathrm{C}$ hingga diperoleh bobot kering konstan. Hasil pengukuran bobot kering dinyatakan dalam satuan $g$ per tanaman.

\section{c. Komponen Hasil Panen}

Komponen hasil panen meliputi jumlah umbi dan bobot umbi per tanaman. Pengamatan jumlah umbi dilakukan dengan cara menghitung umbi dari masing-masing tanaman contoh yang telah memenuhi kriteria panen. Umbi yang telah matang memiliki kriteria kulit berwarna kuning dan telah mencapai ukuran umbi rata-rata. Hasil pengamatan jumlah umbi dinyatakan dalam satuan umbi per tanaman. Umbi yang telah dihitung kemudian ditimbang untuk mengetahui bobot umbi dari masingmasing tanaman contoh. Hasil pengamatan bobot umbi dinyatakan dalam satuan g per tanaman.

d. Serapan Hara Phosfat

Analisis serapan hara phosfat dilakukan pada saat tanaman memasuki fase vegetatif maksimum pada umur 70 hst (Gustianty, 2008). Serapan hara P pada tanaman dihitung menggunakan rumus : Serapan Hara $(\mathrm{P})=$ Kadar Hara Tanaman (\%) x Bobot Kering Tanaman (g).

e. Persentase Kerusakan Tanaman

Tanaman yang mengalami kerusakan akibat serangan hama maupun penyakit dilakukan pengamtan untuk mengetahui persentase kerusakan tanaman menggunakan rumus yang mengacu pada Abadi (2003) dalam Paath (2005) adalah sebagai berikut :

$$
\mathrm{P}=\frac{\mathrm{n}}{\mathrm{N}} \times 100 \%
$$

P : \% kerusakan tanaman (\%), $\mathrm{n}$ : jumlah tanaman rusak, $\mathrm{N}$ : jumlah tanaman yang diamati

\section{Hasil dan Pembahasan}

\section{a. Luas Daun}

Pengamatan luas daun tanaman kentang dilakukan sebanyak dua kali yaitu pada umur 56 dan 70 hst. Hasil analisis ragam parameter luas daun pada kedua umur tersebut menunjukkan bahwa terdapat interaksi antara bakteri endofit dengan cekaman kekeringan. Hubungan interaksi yang terjadi antara kedua faktor tersebut menunjukkan bahwa pada setiap tingkat cekaman kekeringan, pemberian bakteri endofit memberikan pengaruh yang berbeda terhadap luas daun (Tabel 1)

Hasil Uji BNT 5\% terhadap luas daun pada umur 56 hst yang tersaji pada 
tabel 8 menunjukkan bahwa, pada tingkat cekaman kekeringan $100 \%$ kapasitas lapang pemberian bakteri endofit $E$. xiangfangensis dan E. cloaceae tidak memberikan perbedaan terhadap luas daun dibandingkan dengan perlakuan tanpa pemberian bakteri endofit. Pada tingkat cekaman kekeringan $75 \%$ kapasitas lapang pemberian bakteri endofit E. xiangfangensis dan E. cloaceaae menyebabkan perbedaan luas daun dibandingkan dengan perlakuan tanpa pemberian bakteri endofit.

Tabel 1. Rata-Rata Luas Daun Hasil Interaksi Bakteri Endofit dengan Cekaman Kekeringan

\begin{tabular}{|c|c|c|c|c|}
\hline \multirow{3}{*}{ Bakteri } & \multicolumn{4}{|c|}{ Luas Daun $\left(\mathrm{cm}^{2}\right)$ pada Umur 56 hst } \\
\hline & \multicolumn{4}{|c|}{ Cekaman Kekeringan } \\
\hline & $100 \% \mathrm{KL}$ & $75 \% \mathrm{KL}$ & $50 \% \mathrm{KL}$ & $25 \% \mathrm{KL}$ \\
\hline Tanpa bakteri & $167,3 \mathrm{~b}$ & $189,6 \mathrm{~b}$ & $212,4 \mathrm{bc}$ & $103,3 \mathrm{ab}$ \\
\hline E. xiangfangensis & $157,2 \mathrm{~b}$ & $254,8 \mathrm{c}$ & $251,7 \mathrm{c}$ & $131,6 \mathrm{ab}$ \\
\hline E. cloaceae & $125,3 \mathrm{ab}$ & $95,07 \mathrm{a}$ & $82,90 \mathrm{a}$ & $143,7 \mathrm{ab}$ \\
\hline BNT 5\% & \multicolumn{4}{|c|}{61,65} \\
\hline \multirow{3}{*}{ Bakteri } & \multicolumn{4}{|c|}{ Luas Daun $\left(\mathrm{cm}^{2}\right)$ pada Umur $70 \mathrm{hst}$} \\
\hline & \multicolumn{4}{|c|}{ Cekaman Kekeringan } \\
\hline & $100 \% \mathrm{KL}$ & $75 \% \mathrm{KL}$ & $50 \% \mathrm{KL}$ & $25 \% \mathrm{KL}$ \\
\hline Tanpa bakteri & $351,6 \mathrm{~b}$ & $616,0 \mathrm{c}$ & $513,8 \mathrm{bc}$ & $247,2 \mathrm{ab}$ \\
\hline E. xiangfangensis & $378,4 \mathrm{~b}$ & $473,2 \mathrm{bc}$ & $244,7 \mathrm{ab}$ & $413,4 \mathrm{~b}$ \\
\hline E. cloaceae & $457,5 \mathrm{bc}$ & $182,1 \mathrm{a}$ & $154,5 \mathrm{a}$ & $368,4 \mathrm{~b}$ \\
\hline
\end{tabular}

Keterangan $:$ hst $=$ hari setelah tanam, $\mathrm{tn}=$ tidak nyata, $\mathrm{KL}=$ Kapasitas Lapang, BNT $=$ Beda Nyata Terkecil. Bilangan yang diikuti oleh huruf yang sama, pada kolom perlakuan cekaman yang sama dan pada baris perlakuan bakteri endofit yang sama tidak berbeda nyata berdasarkan uji BNT taraf $5 \%$.

Pemberian bakteri endofit E. endofit E. cloaceae yaitu $95,07 \mathrm{~cm}^{2}$ atau xiangfangensis menyebabkan perbedaan luas daun nyata lebih tinggi dibandingkan dengan perlakuan tanpa bakteri endofit dan bakteri endofit E. cloaceae. Rata-rata luas daun yang dihasilkan akibat pemberian bakteri E. xiangfangensis yaitu $254,8 \mathrm{~cm}^{2}$ atau $34,38 \%$ kenaikannya dibandingkan dengan perlakuan tanpa pemberian bakteri endofit. Hal yang berbeda tampak pada pemberian bakteri endofit E. cloaceae memberikan perbedaan luas daun nyata lebih rendah dibandingkan dengan perlakuan tanpa pemberian bakteri endofit. Nilai rata-rata luas daun akibat pemberian bakteri $49,86 \%$ lebih rendah dibandingkan dengan perlakuan tanpa pemberian bakteri endofit.

\section{b. Bobot Kering Tanaman}

Hasil analisis ragam parameter bobot kering tanaman menunjukkan bahwa terdapat interaksi antara bakteri endofit dengan cekaman kekeringan umur 56 dan 70 hst. Hubungan interaksi yang terjadi antara kedua faktor tersebut menunjukkan bahwa pada setiap tingkat cekaman kekeringan, pemberian bakteri endofit memberikan pengaruh yang berbeda terhadap bobot kering tanaman (Tabel 2) 
Dari Tabel 2 diketahui bahwa pada tingkat cekaman kekeringan 100\% kapasitas lapang, tanpa bakteri endofit, bakteri endofit E. xiangfangensis dan bakteri endofit E. cloaceae tidak memberikan perbedaan terhadap bobot kering tanaman pada umur 56 hst. Pada tingkat cekaman kekeringan $75 \%$ kapasitas lapang pemberian bakteri endofit E. xiangfangensis memberikan perbedaan terhadap bobot kering tanaman dibandingkan dengan perlakuan tanpa pemberian bakteri endofit, namun tidak berbeda dengan pemberian bakteri endofit E. cloaceae.
Nilai rata-rata bobot kering tanaman akibat pemberian bakteri endofit E. xiangfangensis nyata lebih tinggi dibandingkan nilai rata-rata bobot kering tanaman tanpa pemberian bakteri endofit, persentase peningkatannya yaitu 80,27\%. Pemberian bakteri endofit E. cloaceae tidak memberikan perbedaan ratarata bobot kering tanaman dibandingkan dengan rata-rata bobot kering tanaman tanpa pemberian bakteri endofit. Persentase peningkatan bobot kering tanaman akibat pemberian bakteri endofit E. cloacae dibandingkan nilai ratarata bobot kering tanaman tanpa pemberian bakteri endofit yaitu 33,28\%.

Tabel 2. Rata-Rata Bobot Kering Tanaman Hasil Interaksi Bakteri Endofit dengan Cekaman Kekeringan

\begin{tabular}{|c|c|c|c|c|}
\hline \multirow{3}{*}{ Bakteri } & \multicolumn{4}{|c|}{ Bobot Kering Tanaman (g) pada Umur 56 hst } \\
\hline & \multicolumn{4}{|c|}{ Cekaman Kekeringan } \\
\hline & $100 \% \mathrm{KL}$ & $75 \% \mathrm{KL}$ & $50 \% \mathrm{KL}$ & $25 \% \mathrm{KL}$ \\
\hline Tanpa bakteri & $2,05 \mathrm{~b}$ & $1,31 \mathrm{a}$ & $1,93 \mathrm{~b}$ & $1,60 \mathrm{ab}$ \\
\hline E. xiangfangensis & $1,90 \mathrm{~b}$ & $2,37 \mathrm{~b}$ & $3,58 \mathrm{c}$ & $1,52 \mathrm{ab}$ \\
\hline E. cloaceae & $1,63 \mathrm{ab}$ & $1,75 \mathrm{ab}$ & $2,25 \mathrm{~b}$ & $1,78 \mathrm{ab}$ \\
\hline \multirow[t]{2}{*}{ BNT 5\% } & \multicolumn{4}{|c|}{0,511} \\
\hline & Bobot I & g Tanams & g) pada $U_{r}$ & 70 hst \\
\hline \multirow[t]{2}{*}{ Bakteri } & \multicolumn{4}{|c|}{ Cekaman Kekeringan } \\
\hline & $100 \% \mathrm{KL}$ & $75 \% \mathrm{KL}$ & $50 \% \mathrm{KL}$ & $25 \% \mathrm{KL}$ \\
\hline Tanpa bakteri & $4,33 \mathrm{~b}$ & $4,27 \mathrm{~b}$ & $4,55 \mathrm{~b}$ & $3,81 \mathrm{ab}$ \\
\hline E. xiangfangensis & $4,16 \mathrm{~b}$ & $5,25 \mathrm{c}$ & $3,47 \mathrm{a}$ & $4,73 \mathrm{bc}$ \\
\hline E. cloaceae & $5,86 \mathrm{c}$ & $3,33 \mathrm{a}$ & $3,54 \mathrm{ab}$ & $4,40 \mathrm{~b}$ \\
\hline
\end{tabular}

BNT 5\% 0,617

Keterangan $:$ hst $=$ hari setelah tanam, $\mathrm{tn}=$ tidak nyata, $\mathrm{KL}=$ Kapasitas Lapang, $\mathrm{BNT}=\mathrm{Beda}$ Nyata Terkecil. Bilangan yang diikuti oleh huruf yang sama, pada kolom perlakuan cekaman yang sama dan pada baris perlakuan bakteri endofit yang sama tidak berbeda nyata berdasarkan uji BNT taraf 5\%.

\section{c. Komponen Hasil Panen}

Hasil analisis ragam terhadap komponen hasil panen diantaranya ialah jumlah umbi per tanaman dan bobot umbi per tanaman menunjukkan bahwa tidak terdapat interaksi antara perlakuan bakteri endofit dengan cekaman kekeringan. Perlakuan bakteri endofit 
K. E. Maharina, N. Aini dan L. Q. Aini / Buana Sains Vol 17 No 1: 85 - 94

dan cekaman kekeringan secara mandiri juga tidak memberikan pengaruh yang nyata terhadap komponen hasil panen kentang (Tabel 3). Data yang dianalisis merupakan data hasil transformasi dalam bentuk $\sqrt{(x+0,5)}$ untuk data parameter jumlah umbi per tanaman dan bobot umbi per tanaman. Tabel 3 Menunjukkan Pemberian bakteri endofit tidak berpengaruh terhadap rata-rata jumlah umbi per tanaman maupun bobot umbi per tanaman. Hal serupa juga tampak bahwa tingkat cekaman kekeringan 75\%, $50 \%$ dan $25 \%$ kapasitas lapang juga tidak memberikan perbedaan rata-rata jumlah umbi per tanaman maupun bobot umbi per tanaman dibandingkan dengan perlakuan tanpa bakteri endofit. Hal ini menunjukkan bahwa hasil panen tidak dipengaruhi oleh kedua perlakuan

Tabel 3. Rata-rata Komponen Hasil Panen Kentang Hasil Perlakuan Bakteri Endofit dan Cekaman Kekeringan

\begin{tabular}{lcc}
\hline \multirow{2}{*}{ Perlakuan } & \multicolumn{2}{c}{ Hasil Panen Tanaman pada Umur Panen 91 hst } \\
\cline { 2 - 3 } & $\begin{array}{c}\text { Jumlah Umbi } \\
\text { (umbi per tanaman) }\end{array}$ & $\begin{array}{c}\text { Bobot Umbi } \\
\text { (g per tanaman) }\end{array}$ \\
\hline Bakteri & 2,21 & 62,63 \\
Tanpa bakteri & 2,33 & 60,40 \\
E. xiangfangensis & 2,02 & 58,77 \\
E. cloaceae & tn & tn \\
\hline \multicolumn{1}{c}{ BNT 5\% } & 2,19 & 62,22 \\
\hline Cekaman Kekeringan & 2,39 & 65,64 \\
100\% kapasitas lapang & 2,50 & 61,75 \\
$75 \%$ kapasitas lapang & 1,67 & 52,78 \\
50\% kapasitas lapang & th & \\
25\% kapasitas lapang & & .
\end{tabular}

BNT 5\% tn tn

Keterangan $:$ hst $=$ hari setelah tanam, $\mathrm{tn}=$ tidak nyata, $\mathrm{BNT}=$ Beda Nyata Terkecil. Bilangan yang diikuti oleh huruf yang sama, pada kolom umur pengamatan dan perlakuan yang sama tidak berbeda nyata berdasarkan uji BNT taraf 5\%. Uji lanjut parameter jumlah umbi dan bobot umbi per tanaman menggunakan data hasil transformasi $\sqrt{(x+0,5)}$.

\section{d. Analisis Serapan Hara Phosfat (P) pada Tanaman Kentang}

Analisis serapan hara $\mathrm{p}$ dilakukan terhadap tanaman kentang pada umur 70 hst. Hasil analisis ragam terhadap serapan hara $\mathrm{p}$ pada tanaman menunjukkan bahwa terdapat interaksi antara perlakuan bakteri endofit dengan cekaman kekeringan (Tabel 4).

Hasil Uji BNT 5\% tanaman kentang umur 70 hst menunjukkan bahwa, pada tingkat cekaman kekeringan
100\% kapasitas lapang pemberian bakteri endofit tidak memberikan perbedaan terhadap serapan hara $\mathrm{p}$ pada tanaman. Pada tingkat cekaman kekeringan 75\% kapasitas lapang pemberian bakteri endofit E. xiangfangensis menyebabkan perbedaan serapan hara $\mathrm{p}$ pada tanaman nyata lebih tinggi dibandingkan dengan pemberian bakteri endofit E. cloacea, namun tidak berbeda dengan perlakuan tanpa bakteri endofit. Rata-rata Serapan hara $\mathrm{p}$ akibat pemberian bakteri $E$. 
K. E. Maharina, N. Aini dan L. Q. Aini / Buana Sains Vol 17 No 1: 85 - 94

xiangfangensis yaitu 1,178 atau $69,98 \%$ kenaikannya dibandingkan dengan perlakuan bakteri endofit E. cloaceae,

sedangkan dengan perlakuan tanpa pemberian bakteri endofit peningkatannya yaitu 22,20\%.

Tabel 4. Rata-rata Serapan Hara Phosfat (P) pada Tanaman Kentang

\begin{tabular}{lcccc}
\hline \multirow{2}{*}{ Bakteri } & \multicolumn{4}{c}{ Serapan Hara Phosfat (P) pada Umur 70 hst } \\
\cline { 2 - 5 } & $100 \% \mathrm{KL}$ & $75 \% \mathrm{KL}$ & $50 \% \mathrm{KL}$ & $25 \% \mathrm{KL}$ \\
\cline { 2 - 5 } & $1,068 \mathrm{bc}$ & $0,964 \mathrm{ab}$ & $1,329 \mathrm{c}$ & $0,887 \mathrm{ab}$ \\
\hline Tanpa bakteri & $1,197 \mathrm{bc}$ & $1,178 \mathrm{bc}$ & $1,027 \mathrm{~b}$ & $1,155 \mathrm{bc}$ \\
E. xiangfangensis & $1,485 \mathrm{c}$ & $0,693 \mathrm{a}$ & $0,865 \mathrm{ab}$ & $1,335 \mathrm{c}$ \\
E. cloaceae & & &
\end{tabular}

BNT 5\% 0,298

Keterangan $:$ hst $=$ hari setelah tanam, tn $=$ tidak nyata, $\mathrm{KL}=$ Kapasitas Lapang, BNT $=$ Beda Nyata Terkecil. Bilangan yang diikuti oleh huruf yang sama, pada kolom perlakuan cekaman yang sama dan pada baris perlakuan bakteri endofit yang sama tidak berbeda nyata berdasarkan uji BNT taraf 5\%.

Tabel 5. Rata-rata Persentase Kerusakan Tanaman Hasil Perlakuan Bakteri Endofit dan Cekaman Kekeringan

\section{Perlakuan}

Persentase Kerusakan Tanaman (\%)

Bakteri

Tanpa bakteri 36,09

E. xiangfangensis

31,58

E. cloaceae 38,35

\section{BNT 5\%}

tn

Cekaman Kekeringan

100\% kapasitas lapang 31,58

75\% kapasitas lapang 36,09

$50 \%$ kapasitas lapang 39,10

25\% kapasitas lapang 34,59

BNT 5\% tn

Keterangan $:$ hst $=$ hari setelah tanam, $\mathrm{tn}=$ tidak nyata, $\mathrm{BNT}=$ Beda Nyata Terkecil. Bilangan yang diikuti oleh huruf yang sama, pada kolom umur pengamatan dan perlakuan yang sama tidak berbeda nyata berdasarkan uji BNT taraf 5\%. Uji lanjut menggunakan data hasil transformasi $\sqrt{(x+0,5)}$. 


\section{e. Persentase Kerusakan Tanaman}

Gejala kerusakan tanaman yang disebabkan oleh hama dan penyakit juga turut diamati guna mengetahui pengaruh perlakuan terhadap tingkat kerusakan tanaman akibat serangan hama dan penyakit yang dinyatakan dalam bentuk persentase (\%). Berdasarkan hasil analisis ragam diketahui bahwa tidak terdapat interaksi antara bakteri endofit dengan cekaman kekeringan yang mempengaruhi persentase kerusakan tanaman. Bakteri endofit dan cekaman kekeringan secara mandiri tidak memberikan pengaruh terhadap persentase kerusakan tanaman. Data yang dianalisis ialah data pengamatan yang telah ditransformasi dalam bentuk bentuk $\sqrt{(x+0,5)}$. Ratarata persentase kerusakan tanaman dapat ditampilkan pada Tabel 5.

Pada Tabel 5 diketahui bahwa bakteri endofit tidak memberikan pengaruh terhadap persentase kerusakan tanaman. Bakteri endofit yang diaplikasikan pada tanaman tidak memberikan perbedaan pada persentase kerusakan tanaman yang diamati. Tingkat cekaman kekeringan juga tidak memberikan perbedaan pada persentase kerusakan tanaman. Hal tersebut menunjukkan bahwa pemberian bakteri endofit maupun tingkat cekaman kekeringan belum mampu memberikan pengaruh terhadap tingkat serangan hama dan penyakit yang menyebabkan kerusakan pada tanaman. Diduga selain faktor perlakuan, perkembangan hama dan penyakit dipengaruhi oleh faktor lingkungan saat budidaya tanaman kentang.

\section{Kesimpulan}

Pada tingkat cekaman kekeringan 75\% kapasitas lapang dapat memacu potensi bakteri endofit E. xiangfangensis dalam meningkatkan luas daun, bobot kering tanaman, panjang akar serta aktivitas fisiologis yaitu total serapan hara phosfat pada tanaman kentang. Bakteri endofit E. xiangfangensis lebih unggul dalam meningkatkan tinggi tanaman kentang dibandingkan dengan bakteri endofit $E$. cloaceae. Selanjutnya, pada kondisi cekaman kekeringan $50 \%$ kapasitas lapang dan 75\% kapasitas lapang memberikan pengaruh yang berbeda pada hasil pengamatan parameter pertumbuhan panjang akar tanaman kentang.

\section{DAFTAR PUSATAKA}

Anonymous. 2015. What are $\mathrm{El}$ nino and $\mathrm{La}$ Nina. Available at http://oceanservice. noaa.gov//facts/ninonina.btml. Diakses 28 Oktober 2015.

Basu, P. S., A. Sharma, and N. P. Sukumaran. Changes in Net Photosynthetic Rate and Chlorophyll Fluorescence in Potato Leaves Induced by Water Stress. J. Photosynthetica. 3 : 13-19.

Gustianty, L. R. 2008. Kajian Tentang Petumbuhan dan Produksi Kentang (Solanum tuberosum L.) Varietas Granola Asal Biji Botani Melalui Uji Perkecambahan dan Pengaturan Penanaman di Lapangan. Tesis. Sekolah Pascasarjana Universitas Sumatera Utara. Medan.

Hiller,L. K. and R. E Thornton. 2008. Managing Physiological Disorder In Potato Health Management: Plant Health Management Series edited by D. A. Jhonson. The Amarican Phytopatological Society. St. Paul.

Kartini, E. 2014. Pengembangan Biobakterisida yang Memanfaatkan Bahan Aktif Bakteri Endofit Potensial Antagonis untuk Mengendalikan Erwinia carotovora di Umbi Kentang. Skripsi. Fakultas Pertanian Universitas Brawijaya. Malang.

Kementerian Pertanian. 2015. Rencana Strategis Kementerian Pertanian Tahun 2015-2019. Kementerian Pertanian. Jakarta Selatan. 
Monneveux, P, D. A. Ramirez, and M. T. Pino. 2013. Drought Tolerance in Potato (S. tuberosum L.) can We Learn from Drought tolerance research in Cereals. J. Plant. Sci. 205-206 : 76-86.

Paath, J.M. 2005. Pengendalian Penyakit Layu Bakteri Pada Tanaman Tomat Dengan Pestisida Nabati. Eugenia 11 (1) : 47-55.
Yustianita, E. 2015. Karakterisasi dan Uji Bakteri Endofit untuk Pengendalian Ralstonia solanacearum Patogen Penyebab Penyakit Layu pada Tanaman Kentang (Solanum tuberosum L.). Skripsi. Fakultas Pertanian Universitas Brawijaya. Malang. 